\title{
Implementing Service Learning in a General Education Course: What Have We Learned from Our Experiences?
}

\author{
Theresa Lai Yeung Wai-ling \\ Department of Health and Physical Education \\ The Hong Kong Institute of Education
}

\begin{abstract}
A service learning general education course titled, "Global Food Security Crisis and Health", was implemented from Jan 2011 to May 2011. A group of 20 students from various undergraduate programmes of the Hong Kong Institute of Education have participated in the course. Through coursework, participants have acquired an understanding of the popular discourses regarding social and ecological sustainability in the prevailing food systems and food crisis. Among the various teaching and learning approaches, a servicelearning component was integrated to immerse students in practices involved in resolving inequity in food distribution and consumption. Participants expressed that such experience not only allowed them opportunities to apply their knowledge regarding food sustainability to real-life situations, but also gave them experience in addressing food security problems, so that they understand the issues better in a wider context. If this approach is to be implemented for a wider community of students, issues related to human resources will need to be addressed.
\end{abstract}

\section{Introduction}

Service learning is a learning and teaching strategy that integrates community service with experiential learning [1]. Studies suggest that service learning helps to bridge the gap between abstract concepts of theoretical knowledge and the realworld, which not only promotes critical-thinking and problem-solving skills, but also increases exposure to community issues and challenges their concepts of social inequalities [2], [3]. A learning and teaching approach such as this can be relevant and beneficial to teacher education programs $[4,5,6,7]$ in enhancing teaching skills $[8,9]$ and has the potential for empowering pre-service teachers to confront social injustice practices [10].

The Development Blueprint of the Hong Kong Institute of Education has stressed the importance of building students' total learning experience for whole person development, and active engagement of students in service to the community is one of the pathways to achieve it. A series of pilot Service Learning - General Education (SL-GE) courses has been launched in the Institute and implemented by the General Education Office (GEO) and the Student Affairs Office (SAO) since the second semester of 2008. "Global Food Security Crisis and Health" was one of these SL-GE courses. This paper reports the effectiveness of the delivery of this course and will present insights on ways to improve the course along with future developments in service learning courses in the Institute.

\section{Reporting the Implementation of the Service Learning - General Education Course}

\subsection{Design and Details of the Course}

The course, "Global Food Security Crisis and Health", was taught from Jan 2011 to May 2011. This SL-GE course was designed to expose participants to academic and popular discourses related to social and ecological sustainability in the prevailing food systems, and the food crisis. It aimed to enable participants to explore the local and global food supply, understand the present inadequacy in the global food supply system, and examine the relative impacts of technological changes, sociocultural trends, global economic and political activities related to food within a global context. Students were guided to reflect critically about the relationship between food supply and health, and inequity in food distribution, with a view to explore solutions to address current food problems, and consider alternative ways of feeding ourselves for better heath and sustainability.

The course weightings were $60 \%$ lectures and $40 \%$ practicum, including eight three-hour lectures, one field visit and workshop, and 45 service hours, which included an orientation to the partnership organizations, and a final presentation and sharing session. The service-Learning components of the course took the form of community service or work attachment in a concurrent mode in local placements.

\subsection{Implementing the Course}

Twenty students enrolled the course, which had three individuals actively involved in facilitating 
students' learning, namely the course lecturer, the field instructor, and the field supervisor.

2.2.1. The teaching. The role of the course lecturer was to provide knowledge content to the students and to facilitate their examination and integration of concepts and theories acquired in the lectures with their service experiences. The lecturer delivered eight lectures introducing the relevant contents of the course from both global and local perspectives. Through a range of learning and teaching activities, students were guided to examine the local and global food supply and diets from social, cultural and ecological perspectives. They were also required to evaluate the impact of global economic and political activities on food distribution and consumption, and critically analyze the nutritional and health implications brought about by the global food security crisis. At the end of the course, students were expected to demonstrate their understanding of a global overview of the diet consumption pattern and the evolution of agriculture for food with a view to secure food supply; and suggest solutions to problems in relation to food security and health. In addition to the lectures, the students visited the Oxfam Hong Kong Interactive Education Centre to explore the resources for teaching topics relevant to food security and participated in a drama workshop exploring the issues and difficulties faced by the small farmers in the globalized economy.

2.2.2. The service practicum. Placements were arranged for the students in three non-government organizations (NGOs), namely, The Green Idea (Environmental Recycling) Ltd, The Hong Kong Confederation of Trade Union Education Centre and the St James Settlement. The Green Idea is an agency engaged in recycling food waste (mainly from the lunch boxes of primary school students) into useful products such as fish food, organic plant food and anticides. The Hong Kong Confederation of Trade Union Education Centre provides a range of courses for the working class community to empower their self efficacy and enhance their employability. The students' service practicum included a project designed to minimize food waste by collecting the left over unsold vegetables from the markets in Tai Po at the end of each day, and using these vegetables to run a small canteen, providing lunch for the participants of their courses. The St. James Settlement is one of the NGOs operating Food Banks in Hong Kong to provide food for the lowincome families. In monitoring the service practicum, a staff from the Student Affair Office had acted as a field instructor, providing guidance and support to the students during the service practicum (See Table 1). The Student Affairs Officer also liaised with the service agencies to foster students' learning experiences. Additionally, the service agency supervisors of the organizations provided a range of diversified learning opportunities for students in their setting, and they also assess the students' services.

Table 1. Practicum Related Activities

\begin{tabular}{|c|c|c|}
\hline Activity & \begin{tabular}{|c|} 
Objective \\
\end{tabular} & Time \\
\hline $\begin{array}{l}\text { Briefing and } \\
\text { Training } \\
\text { Session }\end{array}$ & $\begin{array}{l}\text { Brief students on the learning } \\
\text { expectations and objectives of } \\
\text { service-learning practicum, and } \\
\text { equip students with the basic skills } \\
\text { required }\end{array}$ & $\begin{array}{c}\text { Week } \\
1\end{array}$ \\
\hline $\begin{array}{l}\text { Group } \\
\text { Meeting }\end{array}$ & $\begin{array}{l}\text { Introduce service agencies and } \\
\text { match students with respective } \\
\text { service agencies }\end{array}$ & $\begin{array}{l}\text { Week } \\
2\end{array}$ \\
\hline $\begin{array}{l}\text { Service } \\
\text { Agency } \\
\text { Orientation }\end{array}$ & $\begin{array}{l}\text { Ensure mutual understanding on } \\
\text { the practicum arrangement among } \\
\text { students, agency and the field } \\
\text { instructor }\end{array}$ & $\begin{array}{c}\text { Week } \\
3\end{array}$ \\
\hline $\begin{array}{l}\text { Pre-Practicum } \\
\text { Consultation } \\
\end{array}$ & $\begin{array}{l}\text { Prepare the learning agreement on } \\
\text { the service practicum }\end{array}$ & $\begin{array}{c}\text { Week } \\
4\end{array}$ \\
\hline \begin{tabular}{|l|} 
Observation \\
Visit \\
\end{tabular} & $\begin{array}{l}\text { Support and review the progress of } \\
\text { students' learning in the practicum }\end{array}$ & $\begin{array}{c}\text { Week } \\
5-7 \\
\end{array}$ \\
\hline $\begin{array}{l}\text { Group } \\
\text { Discussion }\end{array}$ & $\begin{array}{l}\text { Share ideas and feelings towards } \\
\text { the practicum and allow the service } \\
\text { agency supervisor and students to } \\
\text { have a direct communication }\end{array}$ & $\begin{array}{l}\text { Week } \\
8\end{array}$ \\
\hline \begin{tabular}{|l} 
Post- \\
Practicum \\
Personal \\
Consultation \\
\end{tabular} & $\begin{array}{l}\text { Review of learning outcomes and } \\
\text { achievements } \\
\text { Students Submit Self-Evaluation } \\
\text { Questionnaire }\end{array}$ & $\begin{array}{l}\text { Week } \\
9\end{array}$ \\
\hline $\begin{array}{l}\text { Group } \\
\text { Presentation }\end{array}$ & & $\begin{array}{c}\text { Week } \\
10\end{array}$ \\
\hline
\end{tabular}

2.2.3. Assessments. Assessment of learning in the course involved 3 components. The first part was related to the knowledge transmission component of the course and constituted 50\% weighting. Based on a selected topic related to global food supply and human dietary health, students were required to critically evaluate the situation from both the global and local perspectives, and write an essay (2500 words) analyzing the issue from socio cultural, economic, and political perspectives. They should discuss possible solutions for the food issue, taking into consideration global food sustainability and health problems. This assessment is individualbased. Students reflected on their own acquisition of the knowledge from the course. The second part of the assessment of learning was based on a reflective learning journal detailing the process of learning during their service practicum. Performance in the practicum constituted $30 \%$ weighting of the assessment. Before commencement of the service, the field instructors have discussed with the students and assisted them to complete a Service-Learning Agreement, specifying learning objectives, theory integration and performance. During the service, students are required to keep a learning journal to record critical self reflection on the learning process, 
with a view to provide a means to make linkage between the service, the theoretical concepts and their personal experiences. By end of the service practicum, they have to draw a plan for selfadvancement, and make recommendations to the agents which they have provided service. Feedback from the service agency supervisors would also be considered in the assessment. Assessment of this part is also individual-based.

The third part of assessment is an oral presentation in class to report and to share the service learning experiences among the groups. Performance in the final presentation constituted $20 \%$ and assessment is group-based.

\subsection{Evaluating the Course}

While effectiveness of the course will provide information for developing future SL-GE courses in the Hong Kong Institute of Education in terms of criteria such as service mode, duration, roles and responsibilities of stakeholders, and assessment methods, it is imperative to collect feedback from the instructor team (course lecturer, field instructor, field supervisor, and students) related to how they were engaged in the process, and to what extent they perceived the achievements of students' learning outcomes. The evaluation process aimed to explore the effectiveness of the SL-GE course on students' learning outcomes, and to identify factors which enhance or impede students' learning. With reference to the feedback collected from the various parties, recommendations will be made to inform future development and implementation of SL-GE courses Institute. Evaluation was based on students' achievements of the course intended learning outcomes (CILOs) and findings from analyzing the feedback provided by the various parties involved in the course.

\subsubsection{The course intended learning outcomes. As} listed in the course outline, students are expected to display the following learning outcomes by end of the course:

- examine the local and global food supply and diets from different perspectives: social, cultural and ecological;

- evaluate the impact of global economic and political activities on food distribution and consumption;

- critically analyze the nutritional and health implications brought about by the global food security crisis;

- obtain a global overview of the diet consumption pattern and the evolution of agriculture for food with a view to secure food supply; and

- suggest solutions to problems in relation to food security and health.
With reference to the CILOs, qualitative analysis of the students' performance in their reflective papers, the learning journals as well as the oral presentations were conducted. Relevant information was carefully scrutinized and analyzed. Despite there were differences in student abilities, both in the analytic and reflective ability as well as in language proficiency, there was strong evidence supporting the attainment of the CILOs. In general, students were able to identify food security issues, with the support of relevant literatures, examine and discuss the factors underpinning the current situations and outline the implications for health and the environment. The practicum experiences also contributed to attainment of the CILOs in more focused perspectives.

2.3.2. Feedback from stakeholders. Feedback from the students, the course lecturer, the field supervisor and the service agency supervisors was analyzed and a number of findings were recapitulated.

Feedback from the students was generally very positive. In the 'evaluation of teaching questionnaire' completed by the students on completion of the course, the mean scores of the questions (see Table 2) revealed evidences of effective learning and teaching activities employed in the course.

Table 2. The mean scores of the questions related to coursework and learning activities employed in the course

\begin{tabular}{|c|c|c|}
\hline $\begin{array}{l}\text { Q } \\
\text { no. }\end{array}$ & Questions & $\begin{array}{l}\text { Mean } \\
\text { score* }^{*}\end{array}$ \\
\hline Q3 & $\begin{array}{l}\text { The coursework helped me develop the } \\
\text { knowledge and skills identified in the } \\
\text { course objectives. }\end{array}$ & 3.65 \\
\hline Q4 & $\begin{array}{l}\text { The learning activities stimulated my } \\
\text { interests in the subject. }\end{array}$ & 3.53 \\
\hline Q5 & The learning activities inspired me to think & 3.71 \\
\hline
\end{tabular}

In the open-ended feedback section of the student evaluation, they reflected that the coursework and activities in the course had advanced their critical thinking skills and exposure to the community and the real world. Students valued the opportunities to learn through participating in the services provided by the NGOs. They appreciated having gained valuable experiences through the service practicum. They felt that the course allowed them to explore the real life situations, putting knowledge in context and they also indicated that such experiences have strengthened their problem-solving skills and selfmanagement abilities outside the classroom. On the other hand, some students found involving in service-learning practicum rather time-consuming. While the contact hours of a 3-credit point (CP) course are normally 39 hours, this course requires that students have 24 lecture hours plus 45 hours service practicum, not to mention time spent in 
traveling. Despite students enjoyed the mode of learning, they find such arrangement rather demanding. Some students found it difficult to establish working relations within a short time span, and preferred more service hours and less lecturing hours as they treasure the service experiences which is not available in normal courses.

Feedback from the field supervisor was positive; she expressed having attained job satisfaction in taking up the role in the SL-GE course. Yet she opined that some details need to be resolved in future implementations. A field instructor has to spend time becoming familiar with the service agencies, contacting the agency supervisors and visiting them at least twice during the practicum. Before the practicum, the field instructor also needs to brief the students on basic communication skills required in the placement environment. To assess students' performance in the practicum process, the field instructor needs to read through all the learning journals. Therefore a significant amount of time was required, which added a rather heavy workload to her normal routine work. In the future, manpower resources should be carefully managed in future implementations.

Service agency supervisors appreciated this mode of learning, which allowed opportunities for students to experience the frontline of social service settings. Some of them suggested that the course design provide a wider platform for more in-depth sharing of learning from the practicum among supervisors and students. Their comments related to the students' learning were generally positive. Among the comments, commonly found expressions include 'very attentive and responsible', 'creative and expressive in ideas and suggestions', 'possesses problem solving skills', 'keen and co-operative', etc. This reflected that the field supervisors acknowledged the feasibility of such service practicum and value the sharing in the exchange process.

The course lecturer had the pleasure of witnessing the students' joy of learning throughout the course. The service learning mode in the course offered opportunities for students to develop generic skills including critical thinking, problem solving, communicative and collaborative skills. This particular learning and teaching mode also maximized opportunities for interaction between the teacher and the students both inside and outside the classroom. However, it should be noted that there were more administrative matters to deal with as compared to teaching a traditional course. For example, meeting the field instructor with the service supervisors, juggling the lecture schedules to accommodate placement arrangements so that students will not miss lectures due to commitments in services undertaken during school hours, and so forth.

\section{Recommendation}

While Service Learning is found to be an effective mode of learning and teaching, doubling the credit points allotted to the course may help relieve the tension concerning workload, and allow more time for in-depth sharing of learning from the practicum among supervisors and students.

\section{Conclusion}

The Service Learning initiative is clearly a mode that appeals to both the learner and the teacher. All stakeholders involved in the SL-GE course have acknowledged the merits and effectiveness of the course in promoting joyful learning and developing generic skills of the students. Yet the major concerns regarding manpower resources and the workload issues need to be resolved in future implementations.

\section{References}

[1] Hink, S. S. \& Brandell, M. E., "Relationship Between Institutional Support and Campus Acceptance of Academic Service Learning", American Behavioral Scientist, 2000, 43, pp. 868-881.

[2] Furco, A. \& Billig, S., Service Learning: The Essense of the Pedagogy Greenwich, CT: Information Age Publishing, 2002.

[3] Meaney, K. S., Bohler, H. R., Kopf, K., Hernandez, L. $\&$ Scott, L. S., "Service-Learning and Pre-Service Educators' Cultural Competence for Teaching: An Exploratory Study", Journal of Experiential Education, 31(2), pp. 189-208.

[4] Kirtman, L., "Pre-service teachers and mathematics: The impact of service-learning on teacher preparation", School Science and Mathematics, 2008, March, 108(3), pp. 94-102.

[5] Meaney, K., Griffin, K., \& Bohler, H., "Servicelearning: A venue for enhancing pre-service educators' knowledge base for teaching", International Journal for the Scholarship of Teaching and Learning, Publisher, 3(2), 2009, pp. 1-17.

[6] Novak, J., Murray, M., Scheuermann, A., \& Curran, E., "Enhancing the preparation of special educators through service learning: Evidence from two preservice courses", International Journal of Special Education, 2009, 24(1), pp. 32-44.

[7] Watson, D. L., Crandall, J., Hueglin, S., \& Eisenman, P., "Incorporating Service-learning into Physical Education Teacher Education Programs", Journal of Physical Education, Recreation, and Dance, 2002, 73, pp. 50-54.

[8] LaMaster, K. J., "Enhancing Preservice Teachers Field Experiences through the Addition of a Service-learning Component", Journal of Experiential Education, 2001, 24, pp. 27-3.

[9] Lake, V. E., \& Jones, "Service-learning in Early Childhood Teacher Education: Using Service to Put 
Meaning Back into Learning", Teaching and Teacher Education, 2008, 24, pp. 2146-2156.

[10] Baldwin, S. C., Buchanan, A. M., \& Rudisill, M. E., "What teacher candidates learned about diversity, social justice, and themselves from service learning experiences", Journal of Teacher Education, 2007, 58(4), pp. 315-317. 